\title{
Impact of market orientation on competitiveness: Analysis of internationalized medium-sized and large enterprises
}

\author{
Miklós Stocker, Lídia Várkonyi
}

\begin{abstract}
A B S T R A C T
Objective: The objective of this article is to identify the impact of market orientation and its elements on company competitiveness of internationalized medium-sized and large enterprises present in Central Eastern Europe and Western Europe in the period of economic growth.
\end{abstract}

Research Design \& Methods: Quantitative large sample statistical analysis was conducted on a sample of Hungarian internationalized medium-sized and large enterprises $(n=119)$. Data was obtained by the survey method, the MKTOR scale was implemented in the survey and financial data was also included. The sample is representative for size, and the sample size is larger than required. Factor analysis was used to determine the components of market orientation, regression analysis was used to test the hypotheses, and Chi-square test was used to determine differences in the elements of customer orientation.

Findings: Market orientation influences the competitiveness of internationalized medium-sized and large enterprises present in Central Eastern Europe and Western Europe. Among the components of market orientation, competitor orientation had the most significant and most powerful impact on competitiveness and on market performance as well. Interfunctional coordination had significant impact on adaptivity and operationality. However, customer orientation did not have significant impact on either competitiveness or its elements because customer orientation became a threshold capability of the internationalized medium-sized and large enterprises present in Central Eastern Europe and Western Europe.

Implications \& Recommendations: Executive managers of internationalized medium-sized and large enterprises should focus on competitor orientation if they wish to increase their competitiveness and market performance, while maintaining their companies' high level of customer orientation. If managers want to increase their companies' adaptivity and operationality, they should also focus on interfunctional coordination procedures.

Contribution \& Value Added: The main contribution of the article is that customer orientation is a threshold capability of internationalized medium-sized and large enterprises. Moreover, we prove that market orientation and especially competitor orientation increases the competitiveness of internationalized mediumsized and large companies.

\begin{tabular}{|c|c|}
\hline Article type: & research article \\
\hline Keywords: & $\begin{array}{l}\text { company competitiveness; market orientation; competitor orientation; medium-sized } \\
\text { and large enterprises; MKTOR scale }\end{array}$ \\
\hline JEL codes: & M16, F23, L10 \\
\hline Receive & Accepted: 3 November 2021 \\
\hline
\end{tabular}

Suggested citation:

Stocker, M., \& Várkonyi, L. (2022). Impact of market orientation on competitiveness: Analysis of internationalized medium-sized and large enterprises. Entrepreneurial Business and Economics Review, 10(1), 81-95. https://doi.org/10.15678/EBER.2022.100106

\section{INTRODUCTION}

Market orientation and competitiveness are very important topics for executive managers of internationalized enterprises. Especially if the company is present in several markets, market orientation could determine the success of companies, whereas competitive advantage and competitiveness of enterprises are very important goals not only for executives but also for owners and shareholders. 
Competitiveness can be considered on supranational, national, regional, or firm level as well. In this article we concentrate on the company level.

This research focuses on internationalized companies; more precisely, on the companies with exporting activities, which is usually the result of a certain level of development, while being the least risky form of internationalization and, for most companies, the only form (Daszkiewicz \& Wach, 2012; Wach, 2017). The rationale behind the choice is that exporting companies usually perform better than players who stick to their domestic market only because of self-selection, learning by exporting or both (Bernard \& Jensen, 1999; Merino, Monreal-Pérez, \& Sánchez-Marín, 2012; Stocker, 2014; Kazai Ónodi, 2014; Szerb, Márkus, \& Csapi, 2015; Czakó, Juhász, \& Reszegi, 2016; Stocker, 2016; Stocker, 2019).

This study examines medium-sized and large enterprises as these companies are much more under-researched than small and medium-sized enterprises, which contributes to the originality of our article. In the empirical part of the study, we use the well-established enterprise competitiveness survey, which allows our sample to be representative for the size of internationalized medium-sized and large enterprises. Moreover, our sample size is larger than the theoretically expected sample size, which makes our results generalizable.

The broad research question of this article focuses on how market orientation and its components influence company competitiveness and its elements.

In the literature review section, we will overview the existing literature of competitiveness and market orientation, along with previous results of empirical research conducted in the field, so as to construct our hypotheses. The research methodology part will present the population, the sample, the relevant variables and their operationalization, and the statistical methods used to test the hypothesis. To identify the components of market orientation, we conducted factor analysis and calculated several multiple linear regressions with the approved factors so as to test the hypotheses. Our results were then compared with the previous similar results in the existing literature as we will describe in the conclusion at the end of the article, along with limitations and further research opportunities.

\section{LITERATURE REVIEW AND HYPOTHESES DEVELOPMENT}

Competitiveness is an essential topic about business enterprises. Companies strive to become more competitive as they want to perform better than their competitors. Firm competitiveness is defined as follows:

Firm competitiveness is a capability of a firm to sustainably fulfil its double purpose: meeting customer requirements at profit. This capability is realized through offering on the market goods and services which customers value higher than those offered by competitors. Achieving competitiveness requires the firm's continuing adaptation to changing social and economic norms and conditions (Chikán, 2008, pp. 24-25).

Firm-level competitiveness is strongly connected with competitive advantage, which is very important for companies as it is associated with above average profitability. According to Barney (2001), "a firm is said to have a competitive advantage when it is engaging in activities that increase its efficiency or effectiveness in ways that competing firms are not, regardless of whether those other firms are in a particular firm's industry." (pp. 48) The importance of the competitive advantage is underpinned by the fact that in contrary to past research - competitive advantage is considered the primary source of profit differences between firms, instead of industrial effects of external environment (Grant, 1991; Rumelt, 1991).

Competitiveness as a topic is well discussed in Central and Eastern Europe, not only on the corporate level but also on the national and supranational levels. The Global Competitiveness Index is a frequently used measure, but Doyle and Perez-Alaniz (2017) suggest that there is a need for a Sustainability Adjusted Global Competitiveness Index (SGCl) to comprehensively measure sustainable development and sustainable competitiveness in a cross-country context, considering the environmental and social aspects beside the economic ones. The $\mathrm{SGCl}$ is constructed of the dimensions of basic conditions, efficiency enhancers, and innovation conditions. Liu (2017) complements this with a different approach, by stating that country-, industry-, and firm-level competitiveness remain strongly related, not to mention their macro- and microeconomic determinants. 


\section{Company competitiveness index}

Schmuck (2009) created a questionnaire-based competitiveness index to measure company excellence, which includes variables on research and development, change of target markets, adaptation to changes, rate of marketing budget, participation in strategic alliances, and workforce fluctuation. Schmuck tested the index on 199 organizations, which included companies, local government organizations, and non-governmental organizations.

Laufente, Szerb and Rideg (2016) created a firm-level competitiveness index (CI) based on 10 mutually dependent pillars: human capital, product, domestic market, networks, technology, decision making, strategy, marketing, internationalization, and online presence. This index is widely used in the literature by Laufente, Leiva, Moreno-Gómez and Szerb (2020), Márkus and Rideg (2021), Carmona and Gomes (2021), Lányi, Hornyák and Kruzslicz (2021), Dvoulety and Blazková (2021), among others.

In order to measure firm-level competitiveness, Chikán (2006) developed the Company Competitiveness Index (CCI), which is constituted of capabilities, operationality (O), adaptivity (A), and market performance (MP), as we present in Figure 1 below. Operationality is constituted of costs and prices, quality, time, flexibility and service indicators, while adaptivity consists of market relations, human preparedness, and organisational responsiveness measures. Market performance is measured by return on sales (ROS) and market share, both relative to industry average. The logic behind the index can be expressed with the formula (1), which means, that the "measure of competitiveness is the proportion of the combined degree of Operationality and Adaptability recognized by the market" (Chikán, 2006, pp. 44).

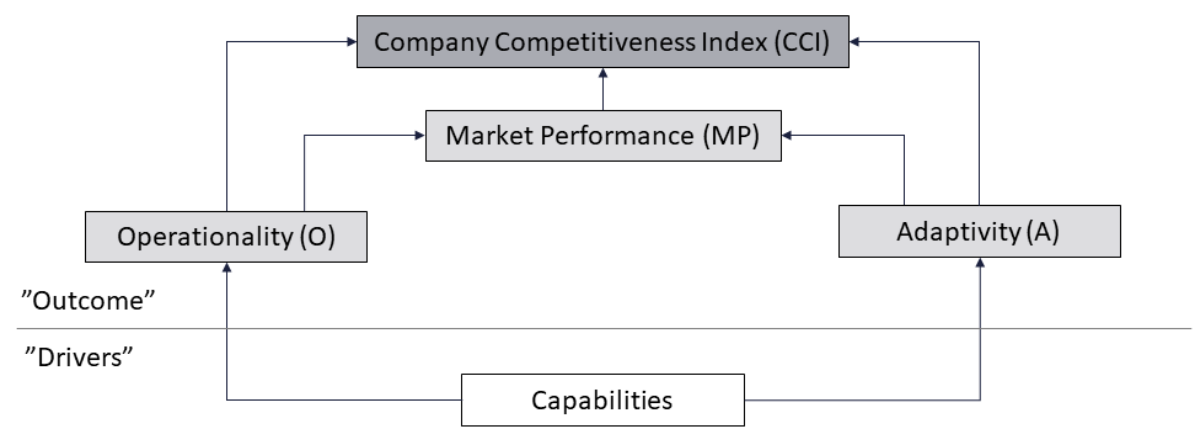

Figure 1. Construction of the Company Competitiveness Index Source: own elaboration based on Chikán (2006).

$$
C C I=(O+A) \times M P
$$

The $\mathrm{CCl}$ model was tested on a sample of hundreds of Hungarian firms and proved to be a statistically adequate measure of firm-level competitiveness. Since performance indicators are already incorporated in the index, we may consider it a higher-level demonstrator of success (Chikán, 2006; Losonci \& Borsos, 2015; Chikán, Czakó, Kiss-Dobronyi \& Losonci, 2022). In this article, we will use the $\mathrm{CCl}$ to measure company competitiveness.

\section{Market orientation and measurement}

Market orientation was a vaguely used concept until in the 1990s the need for a more concrete exploration arose and some measurement approaches were developed. Most research (Chao \& Spillan, 2010; Dubihlela \& Dhurup, 2015; Hussain, Ismail, \& Akhtar, 2015; Mahmoud, 2011; Mokhtar, Yusoff, \& Ahmad, 2014; Nurhilalia, Rahman, Mahlia, Jusni, \& Aditya, 2019; Udriyah, Tham, \& Azam, 2019) build on either of the MARKOR scale proposed by Kohli and Jaworski (1990) or the MKTOR scale developed by Narver and Slater (1990).

Kohli and Jaworski $(1990$, p. 6) consider market orientation to be the implementation of the marketing concept, which refers to "the organization-wide generation of market intelligence pertaining to current and future customer needs, dissemination of the intelligence across departments, and organization-wide responsiveness to it." The MARKOR scale measures these aspects. 
The other widely used measurement approach was developed by Narver and Slater (1990). They identify three behavioural components that constitute market orientation: customer orientation, competitor orientation, and interfunctional coordination. Moreover, they propose two decision criteria long-term focus and profitability - which later studies excluded from the model. Their measurement scale is referred to as MKTOR.

Oczkowski and Farrell (1998) suggest that MKTOR is a better indicator than MARKOR for explaining variances in business performance, while Cano, Carrillat, and Jaramillo (2004) found that market orientation has a stronger effect on business performance when measured with the MARKOR rather than the MKTOR scale. Farrell and Oczkowski (1997) draw attention to problems regarding the validity of both scales and propose excluding some questions. Kiss, Szakály, and Kovács (2020) also argue that some items should be excluded from the MKTOR scale.

Hult, Ketchen, and Slater (2005) found positive connection between each of the market orientation measurement approaches (MKTOR, MARKOR) and responsiveness, which then showed a positive relation to performance, although no direct link could be found between either of them and performance. The authors emphasise that the scales represent different antecedents of performance, so instead of choosing one over the other, both of the two concepts and broader models should be used, so linking market orientation directly to performance can be avoided.

Kohli and Jaworski (1990) propose that business performance is a consequence of market orientation, moderated by supply- and demand-side factors: market turbulence and competition have a positive impact on business performance while technological turbulence and the general economic state have a negative one. Pursuing market orientation is only worthwhile when the results outweigh the (often significant amount of) invested resources. Especially because to achieve the desired performance effects, the quality of market orientation needs to be ensured through the quality of market intelligence and the execution of the marketing plan. Since it requires certain capabilities and resources that are not easily acquired, market orientation can be a source of sustainable competitive advantage, which agrees with the model proposed by Hult et al. (2005).

Ketchen, Hult and Slater (2007) state that market orientation and customer orientation should not be interpreted on one continuum but as elements of a two-dimensional approach along the axes of propensity to satisfy customer needs in the present and in the future. From a different viewpoint, Ferrell, Gonzalez-Padron, Hult, and Maignan, (2010) explain the contrast between market orientation and stakeholder orientation by arguing that while the first one only indirectly considers the stakeholders alongside customers and competitors, the latter does not have a general priority order and is rather situation-dependent. Nonetheless, the authors identify an overlap between the two in the positive relationship between market orientation behaviours and stakeholder orientation as responsible behaviours towards stakeholders. In line with the concept introduced by Ferrell et al. (2010), Vaitoonkiat and Charoensukmongkol (2020) demonstrate evidence that not only customer and competitor orientation but also employee orientation have a significant positive effect on performance but shareholder orientation does not.

Export market orientation can be viewed as the market orientation concept applied to the export market(s), although a strong market orientation on a firm's domestic market does not determine the same level of capability on the export market by default (Cadogan, Paul, Salminen, Puumalainen, \& Sundqvist, 2001). A widely used operationalization of the indicator is proposed by Cadogan, Diamantopoulos, and Mortanges (1999), who employ an adjusted version of the MARKOR scale (Kohli, Jaworski, \& Kumar, 1993) to the export context, while also using the original Narver and Slater (1990) market orientation scale, among other instruments. Several studies found evidence for a significant relationship between export market orientation and export performance of SMEs (Abiodun \& Mahmood, 2015; Acikdilli, Mintu-Wimsatt, Kara, \& Spillan, 2020; Singh \& Mahmood, 2013), other for their indirect relationship (Pascucci, Bartoloni, \& Gregori, 2016), still other discovered no connection between the two elements (Acosta, Crespo, \& Agudo, 2018; Godwin Ahimbisibwe, \& Abaho, 2013).

Based on the meta-analysis conducted by Cano et al. (2004), we may say that country is not a moderator of the relationship between market orientation and business performance, and neither gross domestic product (GDP) nor human development index (HDI) have a significant effect on the relationship. Furthermore, they found that culture (individualism/collectivism) does not impact the relationship 
between market orientation and performance, which agrees with the findings of Deshpande, Farley, and Webster (2000). The latter imply, that the results of analyses on the relationship between market orientation and performance can be generalized across countries of varying GDP, HDI, and culture.

Raju, Lonial, and Crum (2011) highlight the differences in the role of market orientation for larger firms and SMEs. These differences may come for example from higher level of innovativeness, customer contact, and output flexibility in the case of SMEs. The authors suggest that the relationship between market orientation and performance can be generally stronger in the case of SMEs than in that of large corporations. At the time of the study by Hooley et al. (2000), both examined economies of Hungary and Poland just started their transition towards a market-driven setting, so their results may differ from today's. The sector and the market type (consumer vs industrial, services vs manufacturing, fast moving vs durables) were not found to be differentiating factors on the level of market orientation. On the other hand, small yet significant differences appeared in terms of firm size: smaller companies demonstrated a slightly higher level of market orientation.

Gyulavári, Csepeti, and Nagy (2012) in the frames of the previous round of enterprise competitiveness survey assessed the relationship between market orientation and company competitiveness in times of recession using cluster analysis. They found that the better the performance of companies, the higher the level of their market orientation (and its dimensions), while significant differences can only be identified in certain cases, thus limiting generalizable conclusions. When examining the effect of market orientation on the various performance indicators, the authors revealed that competitor orientation impacted most of the studied entities, then interfunctional coordination, while customer orientation only had a significant effect on one of them.

According to the past theoretical constructs and empirical results, this article will investigate the relationship between market orientation and company competitiveness. As SMEs-related research already abounds in the literature, this article focuses on medium-sized and large enterprises. We propose the following hypotheses for the investigation:

H1: Market orientation positively impacts firm-level competitiveness of medium-sized and large internationalized companies.

H1a: Customer orientation positively impacts firm-level competitiveness of medium-sized and large internationalized companies.

H1b: Competitor orientation positively impacts firm-level competitiveness of medium-sized and large internationalized companies.

H1c: Interfunctional coordination positively impacts firm-level competitiveness of mediumsized and large internationalized companies.

\section{RESEARCH METHODOLOGY}

The empirical part of this study was based on quantitative methods. We conducted the enterprise competitiveness survey (ECS) in Hungary in 2019 for the sixth time (after 1996, 1999, 2004, 2009, and 2013), in which the questionnaire consisted of four separate sections to record the perceptions of executive level managers in fields of general management, sales and marketing, operations and production, and finances. The perception database was complemented with companies' financial data from 2013-2018. This period showed significant growth. Hungarian GDP increased from 30290 billion HUF in 2013 to 43350 billion HUF in 2018 (Hungarian Central Statistical Office; HCSO, 2021a), which means $7.43 \%$ of nominal CAGR (Compounded Annual Growth Rate) and 3.96\% CAGR without price effect.

\section{Population, sample, and data collection}

The population of the study was Hungarian medium-sized and large enterprises, but since Cano et al. (2004) proved that the country of origin is not a differentiation factor for the relationship between market orientation and performance, we view our sample as one of internationalized companies present in Central Eastern European and Western European countries. 
The established ECS questionnaire was revised by area experts and the actual questionnaires were finalized in the summer of 2018. Data collection was managed by TÁRKI Zrt. between October 2018 and July 2019. The company contacted more than 2000 enterprises, from which 234 answered the questionnaires later fed to the perception database. The financial data of the companies was attached to the perception database from Bisnode database. In the phase of data validation, several companies had to be excluded as they showed strange financial traits or activities, or they had severely missing financial data. After data validation, 209 companies remained in the ECS sample (Chikán, Czakó, Demeter \& Losonci, 2019).

The ECS sample had to focus on medium-sized and large enterprises, which already conducted business in foreign markets at the time of the study. The most important foreign markets of these companies were located in either Western Europe or Central Eastern Europe. The final sample consisted of $n=119$ companies. Table 1 shows the population and the sample. According to the HCSO (2021b), in 2018 there were 2545 medium-sized and 690 large companies in Hungary that conducted export. We used 2018 as point of reference as that is the final year from which we have financial data about the companies in the sample.

According to the HCSO (2021c), the number of registered enterprises in Hungary was 521,003 on 31 December 2018, from which 37562 (HCSO, 2021b) was conducting export, which means $7.2 \%$ of Hungarian enterprises were exporting at the time. To determine the ideal (expected) sampling size, we used the Cochran formula (Cochran, 1963 quoted in Israel, 1992) with 95\% confidence level:

$$
n_{0}=\frac{Z^{2} \times p \times q}{e^{2}}
$$

In the formula, $\mathrm{Z}=1.96, \mathrm{p}=0.072$ (7.2\% export), $\mathrm{q}=0.928$ ( $92.8 \%$ do not export), and $\mathrm{e}=0.05$ (significance level). According to the formula, the expected sample size $n_{0}$ was 103 companies.

As the proportion of medium-sized and large companies in the population ( $79 \%$ and $21 \%)$ and in the sample ( $76 \%$ and $24 \%)$ were very similar - and the sample size $(n=119)$ was even larger than the expected sample size $\left(n_{0}=103\right)$ - the results of the research were representative for Hungarian medium-sized and large internationalized enterprises.

Table 1. Number of companies in the population and the sample

\begin{tabular}{|l|c|c|c|c|}
\hline Companies conducting export in 2018 & \multicolumn{2}{|c|}{ Hungary } & \multicolumn{2}{c|}{ ECS Sample } \\
\hline Type of companies & Number & Proportion & Number & Proportion \\
\hline Exporter medium enterprises & 2545 & $79 \%$ & 90 & $76 \%$ \\
\hline Exporter large enterprises & 690 & $21 \%$ & 29 & $24 \%$ \\
\hline Sum & 3235 & $100 \%$ & 119 & $100 \%$ \\
\hline
\end{tabular}

Source: own elaboration of data from the HCSO (2021a).

\section{Statistical methods}

Calculation of the components of market orientation was based on factor analysis. First, we conducted an exploratory factor analysis to test the related items in the questionnaire. Then, based on its results, we created a modified factor model. To test the hypotheses, we conducted several linear regression analyses to identify the impact of market orientation and its components on the company competitiveness index and its components. Regression analysis was conducted with the enter method and the missing variables were excluded listwise. There was no autocorrelation, which was tested with DurbinWatson test, and no multicollinearity issue under the variables, which was checked with the Pearson correlation coefficient. The Chi-squared test was used to determine whether there was difference in customer orientation according to size (Landau \& Everitt, 2003).

All statistical calculations were made in IBM SPSS Statistics 25, and Microsoft Excel (from Microsoft Office 365 ProPlus) was applied for other calculations. The significance level was set at $p<0.05$. 


\section{Variable operationalization}

The ECS consisted of more than 1300 perception variables and more than 1300 financial variables. The company competitiveness index (CCl) was calculated after Chikán (2006). Market orientation was measured with the MKTOR scale. The variable $\mathrm{k} 12$ in the sales and marketing questionnaire (answered by the sales or marketing directors of the companies) consisted of questions very similar to the MKTOR scale. We complemented it with variable v35e, which assessed knowledge sharing inside the company and which was clearly related to the interfunctional coordination component of the MKTOR scale.

As Farrell and Oczkowski (1997) and Kiss et al. (2020) suggest, the MKTOR scale items should be validated and some items should be excluded, so we conducted an exploratory factor analysis. According to the exploratory factor analysis, the originally selected 10 variables were not ideal for creating the factors of market orientation. Therefore, two variables were excluded to create the ideal factor model, which we present in Table 2 below.

Table 2. Updated factor model of marketing orientation

\begin{tabular}{|l|c|c|c|}
\hline \multicolumn{1}{|c|}{ Survey question included in the factor model } & \multicolumn{2}{|c|}{ Components of Market Orientation } \\
\cline { 2 - 4 } & $\begin{array}{c}\text { Competitor } \\
\text { Orientation }\end{array}$ & $\begin{array}{c}\text { Customer } \\
\text { Orientation }\end{array}$ & $\begin{array}{c}\text { Interfunctional } \\
\text { Coordination }\end{array}$ \\
\hline $\begin{array}{l}\text { My company is better at customer value creation than its } \\
\text { competitors. }\end{array}$ & 0.537 & $\mathbf{0 . 6 0 9}$ & 0.338 \\
\hline $\begin{array}{l}\text { Customer engagement is more important to my company } \\
\text { than to competitors. }\end{array}$ & 0.339 & $\mathbf{0 . 7 6 5}$ & -0.130 \\
\hline $\begin{array}{l}\text { My company responds to customer needs more efficiently } \\
\text { than its competitors. }\end{array}$ & 0.257 & $\mathbf{0 . 6 6 5}$ & 0.104 \\
\hline $\begin{array}{l}\text { My company responds to competitors' moves faster than } \\
\text { the other competitors. }\end{array}$ & $\mathbf{0 . 8 0 7}$ & 0.301 & 0.078 \\
\hline $\begin{array}{l}\text { My company better follows the movements of } \\
\text { competitors than the other players on the market. }\end{array}$ & $\mathbf{0 . 8 7 2}$ & 0.171 & 0.216 \\
\hline $\begin{array}{l}\text { My company understands the industry competition better } \\
\text { than other players on the market. }\end{array}$ & $\mathbf{0 . 8 1 5}$ & 0.275 & 0.039 \\
\hline $\begin{array}{l}\text { The corporate culture supports cooperation among } \\
\text { business units. }\end{array}$ & -0.085 & 0.544 & $\mathbf{0 . 6 5 5}$ \\
\hline $\begin{array}{l}\text { The company uses a tool to help employees share } \\
\text { knowledge. }\end{array}$ & 0.264 & -0.098 & $\mathbf{0 . 8 2 4}$ \\
\hline
\end{tabular}

Source: own elaboration in SPSS.

The factor model's Kaiser-Meyer-Olkin test for sampling adequacy was 0.785 , significance 0.000 , explained variance $-72.798 \%$, and both anti-image matrices satisfy the requirements. Thus, the factor model proved adequate, and all questions/variables belong to the expected components of market orientation.

\section{RESULTS AND DISCUSSION}

The results of the regression models can be seen in Table 3 below. According to the results, the competitiveness of internationalized companies is indeed influenced by market orientation. In our analysis, market orientation has a significant impact on company competitiveness index, along with operationality and adaptivity. However, it is interesting to see that market orientation's influence on market performance emerged as significant only on $p<0.1$ level, which was higher than our $p<$ 0.05 threshold. Still, in the simple linear regression model, competitor orientation also significantly influenced market performance.

The results in Table 3 show that market orientation of medium-sized and large internationalized companies have a positive significant impact on company competitiveness index. Although the explanatory power of the model is rather low $\left(R^{2}=0.100\right)$, the relationship was found as expected, 
which supports hypothesis $\mathrm{H} 1$. Market orientation significantly influences the operationality and adaptivity elements of company competitiveness index as well, however it does not have a significant impact on market performance.

Table 3. Regression models

\begin{tabular}{|l|c|c|c|c|c|}
\hline \multicolumn{1}{|c|}{ Variable / Measure } & $\begin{array}{c}\text { Company } \\
\text { Competitiveness } \\
\text { Index (CCI) }\end{array}$ & $\begin{array}{c}\text { Operationality } \\
\mathbf{( O )}\end{array}$ & $\begin{array}{c}\text { Adaptivity } \\
\text { (A) }\end{array}$ & $\begin{array}{c}\text { Market } \\
\text { Performance } \\
\text { (MP) }\end{array}$ & $\begin{array}{c}\text { Market } \\
\text { Performance (MP) } \\
\text { simple regression }\end{array}$ \\
\hline const. & $27.831^{* * *}$ & $3.696^{* * *}$ & $3.714^{* * *}$ & $3.731^{* * *}$ & $3.733^{* * *}$ \\
\hline Competitor Orientation & $1.499^{*}$ & 0.035 & 0.060 & $0.155^{*}$ & $0.155^{*}$ \\
\hline Customer Orientation & 0.903 & 0.047 & 0.078 & 0.070 & - \\
\hline Interfunctional Coordination & 0.988 & $0.135^{* *}$ & $0.148^{* *}$ & -0.07 & - \\
\hline $\boldsymbol{R}^{\mathbf{2}}$ & $\mathbf{0 . 1 0 0}$ & $\mathbf{0 . 1 1 6}$ & $\mathbf{0 . 1 1 9}$ & $\mathbf{0 . 0 7 4}$ & $\mathbf{0 . 0 6 1}$ \\
\hline F statistics & 3.221 & 3.902 & 4.12 & 2.32 & 5.807 \\
\hline Durbin-Watson & $\mathrm{p}=0.027^{*}$ & $\mathrm{p}=0.011^{*}$ & $\mathrm{p}=0.01^{* *}$ & $\mathrm{p}=0.081$. & $\mathrm{p}=0.018^{*}$ \\
\hline
\end{tabular}

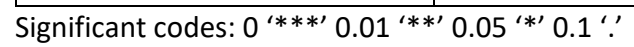

Source: own elaboration in SPSS.

As we break down market orientation to its components, competitor orientation of mediumsized and large internationalized companies emerges as significantly $(p=0.024)$ impacting the company competitiveness index, which supports $\mathrm{H} 1 \mathrm{~b}$ hypothesis. The results also show that one-point increase in competitor orientation increases company competitiveness by 1.499 points. It means that internationalized companies should pay significant attention to competitor orientation as it increases their competitiveness significantly with positive elasticity. Competitor orientation impacts market performance significantly $(p=0.018)$ as well, but does not have significant influence in itself on other elements of competitiveness (adaptivity and operationality).

On the other hand, the interfunctional coordination of medium-sized and large internationalized companies does not have significant influence on company competitiveness index and, therefore, we have to reject hypothesis $\mathrm{H} 1 \mathrm{c}$. Noteworthy, however, is that interfunctional coordination has a significant positive impact on some components of company competitiveness index, namely adaptivity and operationality.

Customer orientation of medium-sized and large internationalized companies did not have significant influence either on company competitiveness index or on any of its components, so we must reject hypothesis $\mathrm{H} 1 \mathrm{a}$. This result is very unexpected, as this relationship is usually taken for granted in most business and marketing handbooks. To understand this issue better, we examined the questions that composed the customer orientation factor. Figure 2 shows the descriptive statistics of the items.

We can see in Figure 2 that mean, median, and mode values of customer orientation components are very high, and their standard deviation or variance are very low ( 5 means absolutely agree, 4 means agree). According to these results, we can see that customer orientation cannot be a differentiating factor on the competitiveness of internationalized medium-sized and large enterprises, as it seems these companies already established a very high level of customer orientation. Therefore, customer orientation appears to be a threshold capability of internationalized medium-sized and large enterprises as its high implementation is a prerequisite to become an internationalized medium or large enterprise.

According to the customer orientation of medium-sized and large internationalized companies, size does not matter at all as there is no significant relationship between company size and any components of customer orientation (accordingly Chi square $p=0.553, p=0.956, p=0.465$ ).

Afsharghasemi, Zain, Sambasivan, and Imm (2013) found that the level of market orientation has a positive impact on competitive advantage, while competitive advantage has a positive impact on internationalization, and the level of market orientation has a positive impact on internationalization, which agrees with our results of market orientation's positive influence on company competitiveness.

The results of Udriyah et al. (2019) show that market orientation positively impact competitive advantage and business performance. Moreover, they found that competitive advantage has a positive impact on business performance. Our results only partly confirm these findings as - although we also 
found the positive impact of market orientation on competitiveness - the positive impact on market performance was not significant on $p<0.05$ level, and we only found the competitor orientation component's impact significant on market performance.

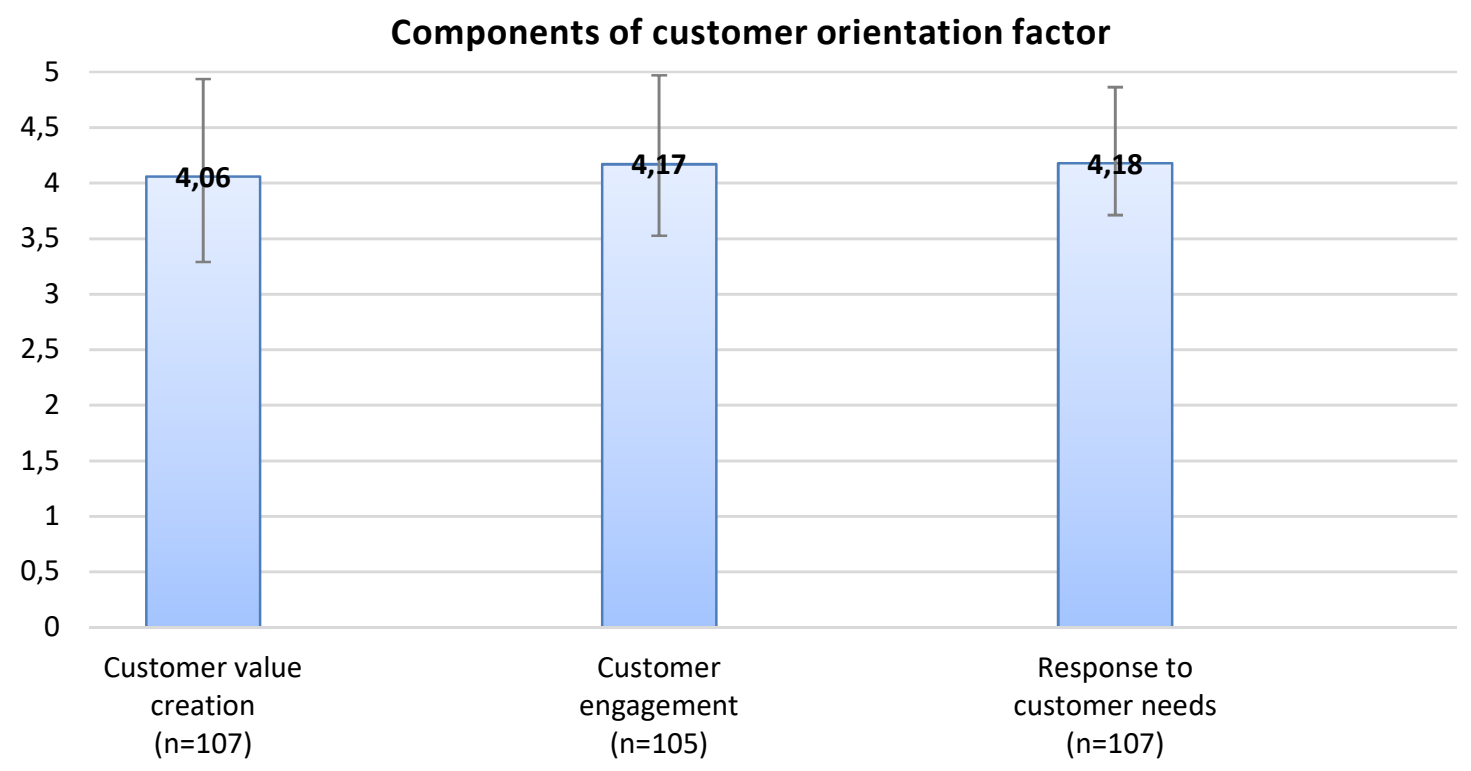

Figure 2. Components of customer orientation factor Source: own elaboration in SPSS.

Several studies like those by Chao and Spillan (2010), Hussain et al. (2015), Kara, Spillan, and DeShields (2005), Mokhtar et al. (2014), and Nurhilalia et al. (2019) assessed elements of market orientation and their impact on business performance. Their results are mostly heterogenous, but in general, in these studies show that some elements of market orientation has a positive impact on business performance and some do not. In our investigation, although market orientation's impact on market performance proved insignificant, competitor orientation in itself had a significant positive impact on market performance.

Schweiger, Stettler, Baldauf, and Zamudio (2019) and Laukkanen, Nagy, Hirvonen, Reijonen, and Pasanen (2013) investigate strategic orientations of firms, and they examined entrepreneurial orientation together with market orientation as the other main strategic orientation. Among the attributes of entrepreneurial orientation dimensions, Wach (2015) lists predicting future market changes and opportunity identification and creation for the proactiveness dimension and competitive advantage, alongside aggressive posturing relative to competitors for the competitive aggressiveness dimension. Furthermore, Akbar, Khan, Wadood, and Bin Bon (2020) suggest that deep understanding of trends and market demands is essential for entrepreneurial orientation. These represent a strong coherence with customer and competitor orientations, so we may assume that in these research streams appear several connections or underlying similar assumptions. According to our results, competitor orientation significantly influences competitiveness and market performance as well.

Soniewicki and Paliszkiewicz (2019) discovered that firms with more intensive knowledge management processes can achieve higher levels of competitiveness, while Wijaya and Suasih (2020) found that through competitive advantage, knowledge management has a significant positive effect on business performance as well. Although we did not investigate deeper the applied knowledge management practices, one part of the interfunctional coordination factor focused on how much the company uses tool(s) for knowledge sharing, which definitely is an element of knowledge management practices or processes. However, our results show that interfunctional coordination did not have significant influence neither on market performance or competitiveness, although it had a significant positive impact on operationality and adaptivity. 


\section{CONCLUSIONS}

Market orientation of internationalized medium-sized and large enterprises present in Central Eastern Europe and Western Europe influences their competitiveness. Among the components of market orientation, competitor orientation had the most significant and most powerful impact on competitiveness and market performance. Interfunctional coordination shows significant influence on adaptivity and operationality. However, customer orientation did not have a significant impact on either competitiveness or its elements because customer orientation became a threshold capability of internationalized medium-sized and large enterprises present in Central Eastern Europe and in Western Europe.

According to the empirical results, both $\mathrm{H} 1$ and $\mathrm{H} 1$ b hypotheses have been supported, as market orientation and competitor orientation had a significant positive impact on firm-level competitiveness of medium-sized and large internationalized companies. The H1a hypothesis was rejected as there was no significant relationship between customer orientation and firm-level competitiveness. The $\mathrm{H} 1 \mathrm{c}$ hypothesis was also rejected as there was no significant relationship between interfunctional coordination and firm-level competitiveness, although interfunctional coordination did show a significant positive impact on adaptivity and operationality.

Therefore, Executive managers of internationalized medium-sized and large enterprises should focus on competitor orientation if they would like to increase their competitiveness and market performance, while they should maintain their companies' high level of customer orientation. If managers would like to increase their companies' adaptivity and operationality, they should also focus on interfunctional coordination procedures.

Executive managers of the companies that wish to internationalize should build a high customer orientation first as it seems to be the entry criterion, later they can also focus on competitor orientation and interfunctional coordination.

Policy-makers should emphasize that customer orientation is just the beginning; if companies reach a high level of customer orientation, they can increase their competitiveness with competitor orientation. Therefore, if domestic medium-sized and large enterprises or internationalized small and medium-sized enterprises would like to become successful internationalized medium-sized and large enterprises, they should focus on their competitor orientation.

This research focused on medium-sized and large internationalized enterprises in Central Eastern Europe and in Western Europe, so its limitation is that it is not generalizable to small and mediumsized enterprises. However, small and medium-sized enterprises and their market orientation are a well-researched topic, so these limitations are not too strong. The period covered by the survey showed stable economic growth period, which can be identified as another limitation of the results. Further limitation is that the detailed decomposition of the sample into industries or strategy types cannot be made as sample sizes would become too small.

Future research should investigate these companies' market orientation and competitiveness, along with market success and survival in the long term, with panel data. Another direction could be the comparison of MLEs with SMEs, with the focus on highlighting size-related differences. Interesting future research area would be to retest the country-of-origin generalizability finding of Cano et al. (2004). Finally, another research direction will be the impact of market orientation and its elements on competitiveness in turbulent times, especially which market orientation elements contributed to the resilience of companies and which did not. Focusing on a selected industry can be also identified as a future research direction.

\section{REFERENCES}

Abiodun, S.T., \& Mahmood, R. (2015). Fostering Export Performance in SMEs: The Roles of Export Market Orientation and Learning Orientation in Turbulent Environment. International Journal of Economic Perspectives, 9(2), 28-48. 
Acikdilli, G., Mintu-Wimsatt, A., Kara, A., \& Spillan, J.E. (2020). Export market orientation, marketing capabilities and export performance of SMEs in an emerging market: a resource- based approach. Journal of Marketing Theory and Practice, 1-16. https://doi.org/10.1080/10696679.2020.1809461

Acosta, A.S., Crespo, Á.H., \& Agudo, J.C. (2018). Effect of market orientation, network capability and entrepreneurial orientation on international performance of small and medium enterprises (SMEs). International Business Review, 27(6), 1128-1140. https://doi.org/10.1016/j.ibusrev.2018.04.004

Afsharghasemi, A., Zain, M., Sambasivan, M., \& Imm, S.N.S. (2013). Market orientation, government regulation, competitive advantage and internationalization of SMEs: A study in Malaysia. Journal of Business Administration Research, 2(2), 13-22. https://doi.org/10.5430/jbar.v2n2p13

Akbar, F., Khan, R. A., Wadood, F., \& Bin Bon, A. T. (2020). Entrepreneurial orientation dimension affects firm performance: A perspective from the Malaysian furniture industry. Entrepreneurial Business and Economics Review, 8(4), 157-181. https://doi.org/10.15678/EBER.2020.080409

Barney, J. B. (2001). Is the resource-based view a useful perspective for strategic management research? Yes. Academy of Management Review, 26(1), 41-56. https://doi.org/10.2307/259393

Bernard, A. B., \& Jensen, J. B. (1999). Exceptional exporter performance: cause, effect, or both?. Journal of international economics, 47(1), 1-25. https://doi.org/10.1016/S0022-1996(98)00027-0

Cadogan, J. W., Diamantopoulos, A., \& Mortanges, D. (1999). A measure of export market orientation: Scale development and cross-cultural validation. Journal of International Business Studies, 30(4), 689-707. https://doi.org/10.1057/palgrave.jibs.8490834

Cadogan, J. W., Paul, N. J., Salminen, R. T., Puumalainen, K., \& Sundqvist, S. (2001). Key antecedents to "export" market-oriented behaviors: a cross-national empirical examination. International Journal of Research in Marketing, 18(3), 261-282. https://doi.org/10.1016/S0167-8116(01)00038-6

Cano, C.R., Carrillat, F.A., \& Jaramillo, F., (2004). A meta-analysis of the relationship between market orientation and business performance: evidence from five continents. International Journal of research in Marketing, 21(2), 179-200. https://doi.org/10.1016/j.ijresmar.2003.07.001

Carmona, L. J. D. M., \& Gomes, G. (2021). Measuring competitiveness through the global competitiveness project framework: the Brazilian experience. Competitiveness Review, 31(3), 439-461. https://doi.org/10.1108/CR12-2019-0164

Chao, M.C.H., \& Spillan, J.E. (2010). The journey from market orientation to firm performance: A comparative study of US and Taiwanese SMEs. Management Research Review. 33(5), 472-483. https://doi.org/10.1108 /01409171011041901

Chikán, A. (2006). A vállalati versenyképesség mérése [Measuring corporate competitiveness]. Pénzügyi Szemle, 51(1), 42-57.

Chikán, A. (2008). National and firm competitiveness: a general research model. Competitiveness Review, 18(1/2), 20-28. https://doi.org/10.1108/10595420810874583

Chikán, A., Czakó, E., Demeter, K., \& Losonci, D. (2019). Versenyben a világgal? - A mikrogazdasági versenyképességi kutatások eredményei, 1995-2018 [In global competition? - Findings of cub's competitiveness research programs, 1995-2018]. Vezetéstudomány, 50(12), 16-31. https://doi.org/10.14267/VEZTUD.2019.12.03

Chikán, A., Czakó, E., Kiss-Dobronyi, B., \& Losonci, D. (2022). Firm competitiveness: A general model and a manufacturing application. International Journal of Production Economics, 243, 1-13. https://doi.org/10.1016/j.ijpe.2021.108316

Czakó, E., Juhász, P., \& Reszegi, L. (2016). Contrasting Methods: An Explorative Investigation on Firm-Level Export Competitiveness Based on Qualitative and Quantitative Research Findings. In P. Trąpczyński, Ł. Puślecki, \& M. Jarosiński (eds), Competitiveness of CEE Economies and Businesses. (pp. 133-148). Berlin: Springer, Cham., https://doi.org/10.1007/978-3-319-39654-5_7

Daszkiewicz, N., \& Wach, K. (2012). Internationalization of SMEs: Context, models and implementation. Gdańsk: Gdańsk University of Technology Publishers.

Deshpande, R., Farley, J. U., \& Webster Jr., F. E. (2000). Triad lessons: Generalizing results on high performance firms in five business-to-business markets. International Journal of Research in Marketing, 17(4), 353-362. https://doi.org/10.1016/S0167-8116(00)00009-4 
Doyle, E., \& Perez-Alaniz, M. (2017). From the concept to the measurement of sustainable competitiveness: social and environmental aspects. Entrepreneurial Business and Economics Review, 5(4), 35-59. https://doi.org/10.15678/EBER.2017.050402

Dubihlela, J., \& Dhurup, M.R. (2015). Determinants of and barriers to market orientation and the relationship with business performance among SMES. The Journal of Applied Business Research, 31(5), 1667-1678. https://doi.org/10.19030/jabr.v31i5.9381

Dvoulety, O., \& Blazková, I. (2021). Determinants of competitiveness of the Czech SMEs: findings from the global competitiveness project. Competitiveness Review, 31(3), 361-378, https://doi.org/10.1108/CR-01-2020-0007

Farrell, M.A., \& Oczkowski, E. (1997). An analysis of the MKTOR and MARKOR measures of market orientation: an Australian perspective. Marketing Bulletin, 8, 30-40.

Ferrell, O.C., Gonzalez-Padron, T.L., Hult, G.T.M., \& Maignan, I. (2010). From market orientation to stakeholder orientation. Journal of Public Policy \& Marketing, 29(1), 93-96. https://doi.org/10.1509/jppm.29.1.93

Godwin Ahimbisibwe, M., \& Abaho, E. (2013). Export entrepreneurial orientation and export performance of SMEs in Uganda. Global Advanced Research Journal of Management and Business Studies, 2(1), 056-062.

Grant, R. M. (1991). The Resource-Based Theory of Competitive Advantage: Implications for Strategy Formulation. California Management Review, 33(3), 114-135. https://doi.org/10.2307/41166664

Gyulavári, T., Csepeti, Á., \& Nagy, G. (2012). A piacorientáció hatása a vállalati versenyképességre. [The Impact of Market Orientation on Competitiveness](TM 32 Working paper). Institute of Business Economics, Competitiveness Research Centre, Corvinus University of Budapest, Hungary.

Hooley, G., Cox, T., Fahy, J., Shipley, D., Beracs, J., Fonfara, K., \& Snoj, B. (2000). Market orientation in the transition economies of central Europe: Tests of the Narver and Slater market orientation scales. Journal of Business research, 50(3), 273-285. https://doi.org/10.1016/S0148-2963(99)00105-8

Hult, G.T.M., Ketchen Jr., D.J., \& Slater, S.F. (2005). Market orientation and performance: an integration of disparate approaches. Strategic Management Journal, 26(12), 1173-1181. https://doi.org/10.1002/smj.494

Hungarian Central Statistical Office. (2021a): 3.1.1. Value, volume and implicit price indices of gross domestic product, annual data (1995-). Retrieved from: https://www.ksh.hu/docs/eng/xstadat/xstadat_annual/i_qpt001.html?lang=en on June 14, 2021

Hungarian Central Statistical Office. (2021b): 3.5.32. Number of enterprises, imports and exports by enterprise size class, types of enterprise and owners (2013-) Retrieved from https://www.ksh.hu/docs/eng/xstadat/xstadat_annual/i_qkt032a.html on June 14, 2021.

Hungarian Central Statistical Office. (2021c): 6.3.2.1.2. Number of registered business units by legal form, 31. December (2011-) Retrieved from https://www.ksh.hu/docs/eng/xstadat/xstadat_annual/i_qvd009b.html on June 14, 2021

Hussain, J., Ismail, K., \& Akhtar, C.S. (2015). Market orientation and organizational performance: case of Pakistani SMEs. Arabian Journal of Business and Management Review, 5(5), 1-6. http://doi.org/10.4172/22235833.1000139

Israel, G. D. (1992). Determining sample size (Fact sheet PEOD-6). Gainesville, FL.: University of Florida.

Kara, A., Spillan, J. E., \& DeShields, O. W. (2005). The effect of a market orientation on business performance: a study of small-sized service retailers using MARKOR scale. Journal of Small Business Management, 43(2), 105-118. https://doi.org/10.1111/j.1540-627x.2005.00128.x

Kazai Ónodi, A. (2014). Export Performance Clusters of the Hungarian Enterprises: What Factors are Behind the Successful Export Activities? Entrepreneurial Business and Economics Review, 2(4), 9-29. https://doi.org/10.15678/EBER.2014.020402

Ketchen Jr., D. J., Hult, T. M., \& Slater, S. F. (2007). Toward greater understanding of market orientation and the resource-based view. Strategic Management Journal, 28(9), 961-964. https://doi.org/10.1002/smj.620

Kiss, M., Szakály, Z., \& Kovács, B. (2020). Az MKTOR piacorientációt mérő modell adaptációja és kapcsolata a vállalati teljesítménnyel [Adaptation of the MKTOR model measuring market orientation and its relation to corporate performance]. Marketing \& Menedzsment, 54(Special Issue 2), 79-90. https://doi.org/10.15170/MM.2020.54.KSZ.II.07

Kohli, A.K., \& Jaworski, B.J. (1990). Market orientation: the construct, research propositions, and managerial implications. Journal of marketing, 54(2), 1-18. https://doi.org/10.2307/1251866 
Kohli, A. K., Jaworski, B. J., \& Kumar, A. (1993). MARKOR: a measure of market orientation. Journal of Marketing research, 30(4), 467-477. https://doi.org/10.2307/3172691

Lafuente, E., Szerb, L., \& Rideg, A. (2016) A system dynamics approach for assessing business competitiveness. In: Research in entrepreneurship and small business. "RENT 2016 : Conference final papers 2016", 1-25.

Lafuente, E., Leiva, J. C., Moreno-Gómez, J., \& Szerb, L. (2020). A nonparametric analysis of competitiveness efficiency: The relevance of firm size and the configuration of competitive pillars. BRQ Business Research Quarterly, 23(3), 203-216. https://doi.org/10.1177/2340944420941440

Landau, S., \& Everitt, B. S. (2003). A handbook of statistical analyses using SPSS. London: Chapman and Hall/CRC.

Laukkanen, T., Nagy, G., Hirvonen, S., Reijonen, H., \& Pasanen, M. (2013). The effect of strategic orientations on business performance in SMEs. International Marketing Review, 30(6), 510-535. https://doi.org/10.1108/ IMR-09-2011-0230

Lányi, B., Hornyák, M., \& Kruzslicz, F. (2021). The effect of online activity on SMEs' competitiveness. Competitiveness Review, 31(3), 477-496. https://doi.org/10.1108/CR-01-2020-0022

Liu, C. (2017). International Competitiveness and the Fourth Industrial Revolution. Entrepreneurial Business and Economics Review, 5(4), 111-133. https://doi.org/10.15678/EBER.2017.050405

Losonci, D., \& Borsos, J. (2015) A lean menedzsment és a vállalati versenyképesség kapcsolata [The relationship between lean management and corporate competitiveness]. Vezetéstudomány, 46 (7), 52-62. https://doi.org/10.14267/VEZTUD.2015.07.05

Mahmoud, M.A. (2011). Market orientation and business performance among SMEs in Ghana. International Business Research, 4(1), 241-251. https://doi.org/10.5539/ibr.v4n1p241

Márkus, G., \& Rideg, A. (2021). Understanding the connection between SMEs' competitiveness and cash flow generation: an empirical analysis from Hungary. Competitiveness Review, 31(3), 397-419. https://doi.org/10.1108/CR-01-2020-0019

Merino, F., Monreal-Pérez, J., \& Sánchez-Marín, G. (2012). Family firm internationalization: Influence of familiness on the Spanish firm export activity (Kiel Working Paper, No. 1770). Kiel Institute for the World Economy (IfW), Kiel.

Mokhtar, S.S.M., Yusoff, R.Z., \& Ahmad, A. (2014). Key elements of market orientation on Malaysian SMEs performance. International Journal of Business and Society, 15(1), 49-64.

Narver, J.C., \& Slater, S.F. (1990). The effect of a market orientation on business profitability. Journal of Marketing, 54(4), 20-35. https://doi.org/10.1177/002224299005400403

Nurhilalia, N., Rahman Kadir, A., Mahlia, M., Jusni, J., \& Aditya, H.P.K.P. (2019). Determinant of Market Orientation on SME Performance: RBV and SCP Perspective. The Journal of Distribution Science, 17(9), 35-45. https://doi.org/10.15722/jds.17.09.201909.35.

Oczkowski, E., \& Farrell, M.A. (1998). Discriminating between measurement scales using non- nested tests and two-stage least squares estimators: the case of market orientation. International Journal of Research in Marketing, 15(4), 349-366. https://doi.org/10.1016/S0167-8116(98)00007-X

Pascucci, F., Bartoloni, S., \& Gregori, G.L. (2016). Export market orientation and international performance in the context of SMEs. Journal of Small Business \& Entrepreneurship, 28(5), 361-375. https://doi.org/10.1080/ 08276331.2016.1167528

Rumelt, R. P. (1991). How much does Industry matter? Strategic Management Journal, 12(3), 167-185. https://doi.org/10.1002/smj.4250120302

Raju, P.S., Lonial, S.C. \& Crum, M.D., (2011) Market orientation in the context of SMEs: A conceptual framework. Journal of Business Research, 64(12), 1320-1326. https://doi.org/10.1016/j.jbusres.2010.12.002

Schweiger, S.A., Stettler, T.R., Baldauf, A., \& Zamudio, C. (2019). The complementarity of strategic orientations: A meta-analytic synthesis and theory extension. Strategic Management Journal, 40(11), 1822-1851. https://doi.org/10.1002/smj.3042

Singh, H. \& Mahmood, R. (2013). Determining the effect of export market orientation on export performance of small and medium enterprises in Malaysia: An exploratory study. Advances in Management and Applied Economics, 3(6), 223-232.

Soniewicki, M. \& Paliszkiewicz, J. (2019). The Importance of Knowledge Management Processes for the Creation of Competitive Advantage by Companies of Varying Size. Entrepreneurial Business and Economics Review, 7(3), 43-63. https://doi.org/10.15678/EBER.2019.070303 
Schmuck, R. (2009). Competitiveness Index: A method of measuring company excellence. Journal of International Scientific Publications, Economy \& Business, 3(7).

Stocker, M. (2014, October 9-11). Business performance of Hungarian exporting companies. First AIB-CEE Chapter Conference: Competitiveness of the CEE region in the global economy. Budapest.

Stocker, M. (2016). Local heroes in Hungary. In: P. Trąpczyński, Ł. Puślecki, \& M. Jarosiński (Eds) Competitiveness of CEE Economies and Businesses. (pp. 211-223). Berlin: Springer, Cham. https://doi.org/10.1007/978-3-319-39654-5_11

Stocker, M. (2019). Survival, growth, and performance of Hungarian international new ventures. Society and Economy, 41(1), 47-64. https://doi.org/10.1556/204.2019.41.1.4

Szerb, L., Márkus, G., \& Csapi, V. (2015). Competitiveness and Internationalisation in the Hungarian Small Business Sector in the 2010s. Studies in International Economics, 1(1), 94-115.

Udriyah, U., Tham, J., \& Azam, S. (2019). The effects of market orientation and innovation on competitive advantage and business performance of textile SMEs. Management Science Letters, 9(9), 1419-1428. https://doi.org/10.5267/j.msl.2019.5.009

Vaitoonkiat, E. \& Charoensukmongkol, P., (2020) Stakeholder orientation's contribution to firm performance. Management Research Review, 43(7), 863-883. https://doi.org/10.1108/MRR-07-2019-0296

Wach, K. (2015). Entrepreneurial Orientation and Business Internationalisation Process: The Theoretical Foundations of International Entrepreneurship. Entrepreneurial Business and Economics Review, 3(2), 9-24. https://doi.org/10.15678/EBER.2015.030202

Wach, K. (2017). Exploring the Role of Ownership in International Entrepreneurship: How does Ownership Affect Internationalisation of Polish Firms?. Entrepreneurial Business and Economics Review, 5(4), 205-223. http://doi.org/10.15678/EBER.2017.050410

Wijaya, P. Y., \& Suasih, N. N. R. (2020). The effect of knowledge management on competitive advantage and business performance: A study of silver craft SMEs. Entrepreneurial Business and Economics Review, 8(4), 105-121. https://doi.org/10.15678/EBER.2020.080406 


\section{Authors}

The contribution share of authors is equal and amounted to $50 \%$ for each of them.

\section{Miklós Stocker}

PhD in Management and Business Administration (2013), Corvinus University of Budapest, Hungary. Associate Professor at the Department of Business Studies of Corvinus University of Budapest, Hungary. His research interests include strategy, business strategy, international new ventures, knowledge management, and sports strategy. Correspondence to: Dr. Miklós Stocker, 8, Fővám tér, E-137, H-1093, Budapest, Hungary; e-mail: miklos.stocker@uni-corvinus.hu ORCID (1) http://orcid.org/0000-0003-2670-6717

\section{Lídia Várkonyi}

Master's-level student in Business Development MSc at Corvinus University of Budapest, Hungary. Her research interest includes international strategy and innovation.

Correspondence to: Ms. Lídia Várkonyi, 8, Fővám tér, E-137, H-1093, Budapest, Hungary; email: lidia.varkonyi@stud.uni-corvinus.hu

ORCID (1) http://orcid.org/0000-0002-8743-6020

\section{Acknowledgements and Financial Disclosure}

The data collection was managed by TÁRKI Zrt. between October 2018 and July 2019. The support for data collection was provided by OTP Nyrt. and Vállalatgazdaságtan Tudományos és Oktatási Alapítvány.

Project no. TKP2020-NKA-02 has been implemented with the support provided from the National Research, Development and Innovation Fund of Hungary, financed under the Tématerületi Kiválósági Program funding scheme."

\section{Conflict of Interest}

The authors declare that the research was conducted in the absence of any commercial or financial relationships that could be construed as a potential conflict of interest.

\section{Copyright and License}

This article is published under the terms of the Creative Commons

Attribution - NoDerivs (CC BY-ND 4.0) License

http://creativecommons.org/licenses/by-nd/4.0/

Published by Cracow University of Economics - Krakow, Poland 
